\title{
BAJO LA TORMENTA
}

Jonathan García Palma*

\section{Josué salió de la habitación y bajó las} escaleras despacio. Se detuvo al llegar al último escalón. La mirada fija en el suelo y la mente aún ocupada en aquello que dejaba atrás. Pensó en volver. Fue in instante. Las frías manos le temblaban un poco. Le era imposible pensar más. Reanudó la marcha después de un último suspiro. Segundos después ya se encontraba en la calle.

Elisa continuaba sentada en su cama. Las palabras de Josué aún giraban en su mente. Intentaba descifrarlas, quería comprender lo sucedido, pero el orgullo le impedía ver más allá de su propia sombra. Se sumergía, cada vez más, en un mar de ideas y sensaciones; en lugar de entender se confundía con mayor fuerza. Rechazaba las frases que le perseguían, negaba con la cabeza y golpeaba la cama con ambas manos. Comenzó a llorar. Se tiró al suelo y continuó golpeando. Lo culpaba a él. Lo maldecía. Lo odiaba.

Él cruzaba la calle cuando recordó lo que escuchara mucho tiempo atrás: "el amor puede convertirse en odio". A su mente llegaron otros pensamientos y unas cuantas imágenes. Ahí estaba Elisa, en su memoria, frente a él. Lo dicho por ella, minutos antes, le perseguía también. Nuevamente se detuvo y quiso mirar hacia atrás. No fue capaz. La razón le obligaba a continuar hacia adelante. Estaba confundido: dos extrañas fuerzas luchaban en su interior y la razón se batía a duelo con una emoción que él desconocía y a la cual le era imposible nombrar.

* Pedagogía (UNAM); cuentista. 
“¡Tú tampoco sabes! ¡Tú tampoco!”, gritaba ella. Las lágrimas rodaron por sus mejillas y llegaron a sus manos, a sus piernas, al suelo. Sentía un gran dolor. “¡Te odio! ¡Te odio!”, exclamaba en medio del 1lanto. “¡Te odio tanto!”, continuaba gritando. Él pudo escucharle a pesar de la distancia. Reconocía que le había herido profundamente; pero pensaba que no estaba lastimado su corazón, sino su orgullo, su soberbia, su egoísmo. "Yo también te odio", susurró él mientras giraba el cuerpo y miraba la ventana de la habitación de Elisa. La luz aún era perceptible. Volvió a caminar, aunque deseaba correr.

Después de unos minutos de llanto y recuerdos, de gritos y golpes al suelo, de pensar y sentir, Elisa comprendió que había algo cierto en las palabras de Josué. Le detestaba y, en aquel instante, hubiera deseado verlo suplicándole, implorando por su perdón. Le había insultado, le había dicho tanto en tan poco tiempo, le había asestado un terrible golpe. Lo destruía. Una frase continuaba en su cabeza y en su corazón: "Tú no sabes amar".

“¡Por supuesto que no sé amar! ¡Claro que no lo sé! ¡Soy egoísta y nunca miro más allá!", exclamaba. "Pero, tú tampoco lo sabes. De lo contrario, nunca me hubieras dicho eso. Tú tampoco me amas, ya lo sé”,

126 añadió, sin gritar, luego de unos cuantos segundos. En ese instante se dejó caer por completo en el suelo y permitió que la ira y todo lo que sentía fluyera libremente. Cerró los ojos y las lágrimas cesaron paulatinamente.

Aparecieron los recuerdos. Regresaron las sensaciones y las imágenes. Se presentaron las palabras y los silencios. Una escena le seguía a otra. Elisa se dejaba mover, se dejaba tocar por la alegría del pasado y por el actual dolor. No opuso resistencia como lo había hecho minutos antes; dejó que la mente lidiara con su corazón. Josué hacía lo mismo bajo la incipiente lluvia que amenazaba con transformarse en tormenta. Él cerró los ojos en medio del camino, se alejó de todo y se dispuso a escuchar su interior. Ambos deseaban encontrar una respuesta.

Un rayo cruzó el cielo y el trueno se escuchó clara y poderosamente al cabo de unos instantes. Después, la oscuridad reinó. Elisa, ya de pie, era incapaz de ver su sombra. Se mantenía inmóvil. Las gotas de lluvia 
golpeaban los cristales de la ventana. La tormenta exterior acompañaba a la que se desarrollaba en su interior.

Afuera, a la distancia, él se encontraba empapado. El viento movía su saco y el cabello violentamente, como deseando cambiarlo de lugar, Pero él se mantenía de pie, en silencio. Sólo podía atender a la tempestad en su interior. La lluvia y los relámpagos no lo inmutaban. De pronto, un par de lágrimas brotaron de sus ojos y alzó la vista al cielo. “i¿Por qué?!”, exclamó. No sabía qué hacer. Estaba confundido, aturdido, conmocionado. Lentamente distinguió algo en su ser: odiaba a Elisa.

"No me hace falta saber más", dijo ella mientras se levantaba del suelo. “Tú tienes razón, tú tienes razón”, expresó al bajar por las escaleras en medio de la penumbra.

"Yo tampoco... Nunca lo he sabido en realidad", dijo él mientras emprendía el camino de regreso.

Segundos después, Elisa ya se encontraba bajo la lluvia. Se preguntaba a dónde ir; cerró los ojos y escuchó el sonido de la tormenta. Cuando alzó la mirada, simplemente corrió hacia la izquierda. Avanzó unos cuantos metros y se topó, frente a frente, con Josué.

"Elisa", dijo él. "Josué", respondió ella.

Se hizo un silencio. La tormenta, testigo de todo, hizo una pausa para permitir que la escena continuara. Era una calma claramente fugaz. La iluminación volvió, aunque débilmente. Un extraño brillo acompañó a la mujer por un instante. Ambos quisieron pronunciar alguna palabra, pero se contuvieron. Las palabras los habían herido antes, así que callaron.

Cada uno respondía sus propias preguntas. Se miraban fijamente. Respiraban agitados. Y así, desde el interior, lograron percibir lo que antes no habían logrado observar. Se abrazaron fuertemente, como si la vida se les fuera en ello.

No necesitaban saber más.

"Es verdad, amar también es morir", dijo él con la voz entrecortada, mientras caía al suelo. La sangre fluía sin cesar por su espalda. Trató de asirse del vestido de Elisa, pero fue imposible. Ella, de pie frente a él, aún sostenía el cuchillo. Le había herido de muerte. 
Un rayo partió el cielo por la mitad. La oscuridad reinó nuevamente y el silencio fue opacado por la tormenta, que reiniciaba con renovada furia.

Josué miró al cielo, susurró el nombre de ella y después cerró los ojos.

La soberbia y la cólera de Elisa se regocijaron, mientras su cuerpo emprendía el camino de regreso a casa, a través de las sombras, en medio de su penumbra interior. 